Agnieszka Imbierowicz

Uniwersytet Wrocławski

\title{
Tabu seksualności seniorów jako wyzwanie dla współczesnej geragogiki
}

\author{
Kiedy się zastanawiam nad starościa, cztery widzę \\ przyczyny, dla których starość zwykliśmy uważać za \\ nieszczęśliwy okres życia: oddala nas ona od życia \\ czynnego, osłabia sity fizyczne, pozbawia nas wszystkich \\ zmysłowych przyjemności, bliska jest śmierci. \\ Cyceron, Katon starszy o starości
}

Społeczeństwa starzeją się, a według demografów zjawisko to będzie podlegało jeszcze większej intensyfikacji. W Polsce obecnie żyje około 4,7 mln kobiet powyżej 60 r. ż. oraz 2 mln mężczyzn powyżej 65 r. ż., a Główny Urząd Statystyczny przewiduje, że liczba ta zwiększy się w roku 2030 do 9,6 mln osób, z czego starszych kobiet jest i będzie dwukrotnie więcej niż starszych mężczyzn ${ }^{1}$. Odpowiedzią na to jest coraz większe zainteresowanie nauki jakością życia seniorów. Rok 2012 został nawet określony Europejskim Rokiem Aktywności Osób Starszych i Solidarności Międzypokoleniowej².

Na tym tle nie dziwi, że coraz prężniej rozwija się geragogika, czyli pedagogika osób starszych, która wspiera procesy adaptacyjne ${ }^{3}$ do starości, ,"analizuje ona ostatnią fazę rozwojową życia ludzkiego, diagnozuje sytuację życiową ludzi starych, określa główne czynniki warunkujące proces starzenia się. Prowadzi badania nad przedłużeniem i optymalizacją warunków aktywnego życia osób w wieku poprodukcyjnym"4. Do jej głównych zadań można zaliczyć między innymi: wychowanie do starości, zapobieganie patologiom jesieni życia, poradnic-

\footnotetext{
1 http://www.stat.gov.pl/gus/5840_648_PLK_HTML.htm, dostęp: 6.06.2012.

2 Informacje o roku tematycznym, $20 \overline{1} 2$ - Europejski Rok Aktywności Osób Starszych i Solidarności Międzypokoleniowej, http://europa.eu/ey2012/ey2012main.jsp?langId=pl\&catId=971, dostęp: 2.06.2012.

3 Na procesy adaptacyjne mają wpływ dwie grupy czynników- wewnętrzne (emocje, motywy, oczekiwania) oraz zewnętrzne (przejawiające się między innymi w działaniach innych osób, $w$ ich traktowaniu osób starszych), zob. Z. Szarota, Gerontologia spoteczna i oświatowa. Zarys problematyki, Wydawnictwo Naukowe Akademii im. A. Frycza Modrzewskiego, Kraków 2004, s. 45.

4 Ibidem, s. 17.
} 
two dla seniorów, terapię, aktywizację, a także przygotowanie do cierpienia i śmierci ${ }^{5}$. Jednak, „problematyka starości traktowana jest na gruncie nauk społecznych "wciąż po macoszemu»"6. Co prawda, powstaje coraz więcej publikacji naukowych na ten temat, jednak brakuje prac komplementarnych, ujmujących sytuację człowieka starszego całościowo, podejmujących również tematy tak trudne, jak seksualność.

Należy przy tym wspomnieć, że możemy mówić o kilku różnych teoriach starzenia się w kontekście gerontologii społecznej, do której zalicza się geragogikę, a mianowicie o teorii deficytu, aktywności oraz o teorii kompetencyjnej. Podstawę tej pierwszej stanowi wiara $\mathrm{w}$ to, że starszy człowiek w miarę upływu czasu funkcjonuje coraz gorzej - zarówno fizycznie, psychicznie, jak i społecznie. Jego ciało staje się coraz bardziej podatne na różnego rodzaju choroby, zmniejsza się aktywność społeczna, maleje inteligencja, spadkowi ulegają również umiejętności adaptacyjne, a on sam staje się coraz bardziej uzależniony od otoczenia (rodziny, lekarzy, terapeutów, opiekunów). W czasach dominacji tej teorii nie zauważano potrzeby edukowania seniorów, którą uważano za bezcelową i z góry skazaną na porażkę. W jej obrębie rozróżnia się teorię defektu oraz teorię ograniczonego używania. Zasadnicza różnica między nimi sprowadza się do tego, czy uznaje się seniorów za osoby niemające wpływu na swój los i zupełnie poddane wpływom zewnętrznym, czy też takie, które dzięki indywidualnej aktywności mogą przedłużyć swoją młodość. Jednak obie te orientacje teoretyczne akcentują kategorię utraty i w najlepszym wypadku mówią o tym, że możliwe jest odłożenie w czasie postępujących negatywnych zmian, nie wspominają natomiast nic o potencjale rozwojowym jesieni życia. Uwagę na to zwracają dopiero teoria aktywności i teoria kompetencyjna. Aktywność w wieku senioralnym jest wciąż możliwa, a nawet zalecana. Według licznych badaczy, zajęcia zastępcze względem pracy zawodowej po przejściu na emeryturę, hobby, związki towarzyskie sprzyjają zwiększonemu zadowoleniu z życia ${ }^{8}$. Kształcenie ma wtedy przede wszystkim pomagać seniorom $\mathrm{w}$ przyjęciu nowej roli życiowej. Z kolei teoria kompetencyjna zakłada, iż aktywność ta „nie powinna sprowadzać się jedynie do aktywności rekreacyjnej. Edukacja pomaga np. utrzymać niezależność osób starszych i przeciwstawiać się stereotypom i ignorancji w zakresie problematyki gerontologicznej"9. Coraz częściej dostrzega się kapitał społeczny seniorów i zachęca się ich do wysiłku edukacyjnego, akcentując to, że w tym wieku wciąż można się rozwijać oraz poszerzać obszar swojej niezależności, co znacząco wpływa

5 Ibidem, s. 19.

Ibidem, s. 10.

J. Halicki, Edukacja seniorów w aspekcie teorii kompetencyjnej. Studium historyczno-porównawcze, Wydawnictwo Uniwersyteckie, Białystok 2000, s. 9-13; Z. Szarota, op. cit., s. 46-47.

8 B. Ziębińska, Uniwersytety Trzeciego Wieku jako instytucje przeciwdziałające marginalizacji osób starszych, Praca doktorska napisana pod kierunkiem prof. zw. dr. hab. Janusza Sztumskiego, Katowice 2007, s. 77-79.

Ibidem, s. 80. 
na jakość życia ${ }^{10}$. Głównym założeniem tej teorii jest przekonanie o tym, że „zachowanie się w wieku starszym, podobnie jak w każdej innej części biografii, musi być rozumiane jako relacja wymagań wobec osób do zasobów umożliwiających sprostanie im"11, co świadczy o jej indywidualistycznym nastawieniu. Każdy etap życia cechuje się bowiem innymi zadaniami rozwojowymi ${ }^{12}$, poza tym zmieniają się wymagania podlegającej ciągłym przemianom rzeczywistości, a wraz z nimi zmieniają się oczekiwania, jakie stawiamy poszczególnym grupom wiekowym, $\mathrm{w}$ tym również seniorom. Teoria kompetencyjna kładzie zatem nacisk na kształtowanie kompetencji osób starszych, rozumianych w wymiarach: fizycznym, poznawczym oraz społecznym, które wspólnie można określić jako „zdolność człowieka do przyjęcia odpowiedzialności za swoje życie i jego samodzielne kształtowanie"13. W jej obrębie mamy do czynienia z kształtowaniem u osób starszych postaw twórczych, afirmacji życia, realizowaniem wartości autotelicznych. Także według psychologii rozwojowej life-span, „człowiek na każdym etapie życia ustawicznie się rozwija i podejmuje określone zadania. Rozwój seksualny w wieku podeszłym również podlega tym prawidłowościom"14.

Na to, jak z owymi zadaniami rozwojowymi radzą sobie osoby starsze, mają wpływ między innymi postawy osób starszych wobec siebie samych, a także nastawienie młodszych pokoleń do nich. Seniorzy najczęściej przejawiają następujące postawy względem jesieni życia:

- konstruktywną,

- zależności,

- obronną,

- wrogości,

- autodestrukcji ${ }^{15}$.

Jest to typologia, która ukazuje możliwe reakcje na swoją starość na kontinuum od najbardziej pożądanej, czyli konstruktywnej, aż do najbardziej szkodliwej, autodestrukcyjnej. Są one uzależnione od osobowości danego seniora, jego do-

\footnotetext{
${ }^{10}$ Oczywiście lansowanie takiego modelu postrzegania starości ma także swoje polityczne uzasadnienie - skoro bowiem i tak nie da się zahamować procesu starzenia się społeczeństw, należy chociaż wykorzystywać efektywnie kapitał społeczny seniorów, który może stanowić pozaekonomiczny czynnik rozwoju gospodarczego państw.

11 J. Halicki, op. cit., s. 11.

12 Wiele z tych zadań dotyczy postaw wobec siebie jako osoby starzejącej się, w tym $\mathrm{m}$. in. realizacji potrzeby przynależności do danej grupy wiekowej, akceptacji zmian zachodzących w organizmie i pogarszania się zdrowia, przygotowania do śmieci partnera/ partnerki itp., zob. E. Kasperek-Golimowska, Starość w perspektywie edukacji promującej zdrowie, [w:] Starość w perspektywie studiów pedagogicznych, pod red. A. Tokaj, Studia i Monografie Wyższej Szkoły Humanistycznej im. Króla Stanisława Leszczyńskiego w Lesznie, Leszno 2008, s. 35.

13 J. Halicki, op. cit., s. 13.

14 M. Cichocka, Biopsychospołeczne uwarunkowania seksualności ludzi starych, [w:] Seksualność w cyklu życia człowieka, pod red. M. Beiserta, PWN, Warszawa 2006, s. 216.

15 Z. Szarota, op. cit., s. 48 oraz A. Kowgier, Życie intymno-emocjonalne osób starszych, Oficyna Wydawnicza „Impuls", Kraków 2010, s. 78.
} 
świadczeń życiowych, wsparcia bliskich osób lub jego braku, społecznego odbioru starości oraz od wielu innych czynników.

Na ewentualne wykształcenie się negatywnych postaw u seniorów mają olbrzymi wpływ poglądy młodszego pokolenia, które są dość niejednoznaczne. Odwołując się do badań amerykańskich z lat osiemdziesiątych, wśród młodych ludzi wyodrębnić można 3 typy wyobrażeń pozytywnych o seniorach oraz 8 negatywnych. Do tych pierwszych zaliczyć należy obraz wzorowego dziadka, mędrca, liberalnej glowy rodu. Natomiast do tych mniej pochlebnych wizerunek: człowieka stabego, bezbronnego, osamotnionego, niezaangażowanego społecznie, nieznośnego sąsiada, zniechęconego, żebraka i włóczęgi, złośliwca i sknery, mruka, ponuraka ${ }^{16}$. Na gruncie polskim Agata Kowgier przeprowadziła badania, których głównym celem było odpowiedzenie na pytanie o to, jakie są opinie studentów na temat życia intymno-emocjonalnego osób starszych. Ich wyniki wskazują między innymi na to, że:

- większości badanych studentów starość kojarzy się negatywnie ${ }^{17}$,

- najwięcej respondentów uznało, że kobiety przestają podejmować aktywność seksualną w wieku 56- 60 lat, a mężczyźni powyżej 66. roku życia ${ }^{18}$,

- za ustanie aktywności seksualnej seniorów odpowiedzialne są w równej mierze czynniki psychologiczne (44\% odpowiedzi), co fizjologiczne (43\% wskazań), natomiast tylko $19 \%$ uważa, że ma to związek z czynnikami społecznymi ${ }^{19}$,

- niemalże połowa ankietowanych stwierdziła, że bycie aktywnym seksualnie seniorem podnosi poziom satysfakcji życiowej ${ }^{20}$.

Geragodzy powinni z tych wyników badań wyciągnąć ważne wnioski, przede wszystkim, że należy pracować nad pozytywnym wizerunkiem starości i sprawić, by kojarzyła się ona młodzieży w sposób mniej negatywny. Jednocześnie warto pamiętać, że skoro młodzi ludzie dostrzegają związek między aktywnością seksualną osób starszych a ich poziomem zadowolenia z życia, stanowi to dobrą podstawę do działań edukacyjnych $\mathrm{w}$ tym zakresie, przede wszystkim do walki ze stereotypami.

Pojęcie stereotypów oraz mitów jest niezwykle ważne w kontekście tematu tej pracy. Narosło ich wiele wokół życia seksualnego seniorów i umacniają one jego tabuizację oraz sprzyjają ageizmowi ${ }^{21}$. Z badań M. Grabowskiej wynika nawet, że na życie seksualne negatywnie wpływają nie tylko stereotypy starości, ale

\footnotetext{
A. Kowgier, op. cit., s. 51.

Ibidem, s. 152.

Ibidem, s. 164.

Ibidem, s. 168

Ibidem, s. 170.
}

21 Pojęcie to „opisuje (..) negatywne stereotypowe postawy społeczne wobec starszych osób. Negatywne nastawienie znajduje swoje odzwierciedlenie w sposobie traktowania ich przez jednostki, instytucje, w języku, w mediach, dowcipach (...)", za: J. Janiszewska-Rain, Okres późnej dorosłości. Jak rozpoznać potencjat ludzi w wieku podeszłym, [w:] Psychologiczne portrety człowieka. Praktyczna psychologia rozwojowa, pod red. A.I. Brzezińskiej, GWP, Gdańsk 2005, s. 612. 
w przypadku kobiet także stereotypy płci²2. Z kolei R. Bartel wśród siedmiu głównych mitów dotyczących starzenia się i starości wymienił mit aseksualności człowieka starego ${ }^{23}$. Agnieszka i Artur Fabiś natomiast wśród najbardziej popularnych mitów dotyczących aktywności seksualnej seniorów wymieniają poniższe:

- "osoby starsze i schorowane nie interesują się seksem,

- osoby starsze i schorowane po 60. roku życia powinny przystosować się do życia w celibacie,

- osoby starsze, które myślą o seksie, są infantylne,

- masturbacja osób starszych jest niezdrowa,

- mężczyźni po 60. roku życia są impotentami,

- u kobiet pożądanie seksualne kończy się wraz z menopauzą,

- kobiety po 60. roku życia nie przeżywają orgazmów,

- abstynencja seksualna po 60. roku życia sprzyja utrzymaniu dobrego stanu zdrowia,

- osoby starsze uprawiają jedynie kontakty waginalne,

- osoby aktywne seksualnie po 60. roku życia są niemoralne" 24 .

Istnienie tych mitów obrazuje to, że wiele osób wciąż nie wie lub ignoruje osiągnięcia współczesnej medycyny, której postęp sprawił już dawno temu, iż stosunkowo łatwo można poradzić sobie z rozmaitymi problemami seksualnymi natury biologicznej. Dużo trudniej zmienić obraz seksualności seniorów w społecznym odbiorze. Niestety wciąż bywa on oceniany w kategoriach estetycznych i etycznych i poddawany jest ostrej krytyce. Wpływ na to ma wciąż pokutujące, zwłaszcza $\mathrm{w}$ społeczeństwach katolickich, postrzeganie seksu przede wszystkim jako sposobu prokreacji25, a także to, iż współcześnie bardzo silny jest kult młodości i ciała ${ }^{26}$.

22 M. Grabowska, Seksualność we wczesnej, średniej i późnej dorosłości. Wybrane uwarunkowania, Wyd. UKW, Bydgoszcz 2011, s. 229-237.

23 Z. Szarota, op. cit., s. 50.

24 A. i A. Fabiś, Aktywność seksualna osób starszych, [w:] Tabu seksuologii. Wątpliwości, trudne tematy, dylematy w seksuologii i edukacji seksualnej, pod red. A. Jodko, Wyd. Academica, Warszawa 2008, s. 158.

$25 \mathrm{~K}$. Imieliński mówi nawet o ideologii reprodukcji, która razem z ideologią seksu waginalnego wpływają na negatywny obraz seksualności seniorów i dlatego należy je obalić, zob. A. Kowgier, op. cit., s. 102-103.

26 „Inną formą współczesnego konsumpcjonizmu, wykreowanego przez modę i rynek medialny, jest kultura powierzchowności. W skali ludzkiej Lasch (1978) określa ją jako kulturę gładkiego ciała, cywilizację depilacji, operacji plastycznych, masaży, gabinetów kosmetycznych, siłowni i kosmetyków przechwytujących i odbijających światło, a zatem technologii z uporem wygładzających i polerujących narcystycznie skoncentrowane na sobie ludzkie ciało. Zdaniem Baumana (1991) destabilizacja ekonomiczna, społeczna i kulturowa współczesnych społeczeństw powoduje, że zanikają tradycyjne podstawy społecznej tożsamości, poza więzią z ludzkim ciałem, ujmowanym jako jedyny trwały czynnik zmiennej tożsamości. Stąd też we współczesnej kulturze pozycja kultu ciała wspomagana kultem młodości i «powierzchowności» jako wartości wysoko stawianej w obecnym społeczeństwie konsumpcyjnym. Jogging, dieta, odchudzanie, zabiegi kosmetyczne, upiększające, poprawiające urodę, przedłużające młodość, zachowujące zdrowie i długowieczność są postrzegane jako manifestacja wolności i ważny czynnik atrakcyjności towarzyskiej, seksualnej i zawodowej ludzi. Egzemplifikacją «kultury powierzchowności» jest dynamiczny, lawinowy wzrost usług służących realizacji tej wartości ludzkiego życia, jaką jest uroda, zdrowie i młodość". K. Rembowska, Kulturowy aspekt przemian rynku uslug, http://www.sse.geo.uni.lodz.pl/uploads/space8/rembowska.pdf, dostęp: 10.06.2012. 
Stare ciało można postrzegać jako „fabrykę obrzydliwości, źródło: nędzy i ohydy, niedoli i udręki” 27, w końcu „wszystko, co młode, jest piękne, a stare według potocznego sposobu myślenia i mówienia - jest brzydkie" 28 . Jest to szczególnie widoczne w przypadku kobiet, wobec których presja młodego i pięknego ciała jest najsilniejsza ${ }^{29}$. Jak pisały B. Bartosz i E. Zierkiewicz: „O ile starszych mężczyzn spostrzega się jako będących w «sile wieku», o tyle starsza kobieta zwykle nie tylko określana jest jako «babcia» czy «staruszka», lecz tak właśnie jest traktowana, tzn. z pobłażaniem, wyrozumiałością itp. (...) «Kurczowe trzymanie się młodości» jest traktowane jako społeczna konieczność, sankcjonowane przez media i przestrzegane też przez same kobiety"30. Dlatego wspomniany kult ciała, młodości i piękna może wpływać bardzo destrukcyjnie na poczucie własnej wartości kobiet, które zauważają na co dzień postępujące zmiany w swojej cielesności. Największym niebezpieczeństwem takiego dyskursu jest sytuacja, w której „wiara w to, że prawdziwa kobieta musi być atrakcyjna fizycznie, sprawia, że kobieta pięćdziesięcioletnia może stać się wrogiem swego ciała"31. Zaczyna ona wydatkować swoją energię na walkę $\mathrm{z}$ oznakami starzenia się, kupuje preparaty przeciwzmarszczkowe, próbuje oszukać czas. Niestety zakres działania najlepszych nawet kosmetyków nie jest w stanie powstrzymać naturalnych procesów starzenia się organizmu, co $\mathrm{w}$ wielu przypadkach może skutkować niechęcią i brakiem akceptacji samej siebie. Bardzo dosadnie wyraża to stwierdzenie: „można powiedzieć, że kobieta przez swoje mocne powiązanie z ciałem, traci swój blask, traci cząstkę siebie. «Wygląd nie jest po prostu jej [kobiety - przyp. A.Z., A.C., M.B.] cechą, jak w przypadku mężczyzny; ona jest swoim wyglądem. Praktycznie każdy aspekt powierzchowności kobiety mówi o tym, kim ona jest i jak należy ją traktować»" ${ }^{32}$. Również tutaj widać niezwykle ważne zadanie dla geragogów, a także pedagogów w ogóle, którzy powinni walczyć z tą podwójną dyskryminacją starszych kobiet (ze względu na wiek i płeć) i już od dzieciństwa kształtować postawy pełne zrozumienia dla specyficznej sytuacji kobiet.

Warto też pamiętać, iż „to nie starość jest okresem trudnym, najcięższy jest sam proces «stawania się człowiekiem starym». K. Wiśniewska-Roszkowska (1986, 1989) mówi o tzw. sztuce starzenia się, przez którą rozumie umiejętność przystosowania się do nowych sytuacji, jakie niesie ze sobą okres starości i tworzenia na nowo sensu swojego życia" ${ }^{\prime 3}$. Takim nowym stanem rzeczy, z którym senior musi

${ }^{27}$ M. Rusiecki, Etyczno-religijne aspekty starszego wieku, [w:] Demograficzne i indywidualne starzenie się, pod red. A. Zych, Wyd. Akademii Świętokrzyskiej, Kielce 2001, s. 65-66.

28 A. Kowgier, op. cit., s. 37.

29 Zob. M. Grabowska, op. cit., s. 94.

30 B. Bartosz, E. Zierkiewicz, Starość w narracjach kobiet młodych i starszych, [w:] Starsze kobiety w kulturze $i$ społeczeństwie, pod red. E. Zierkiewicz, A. Łysaka, Wyd. MarMar, Wrocław 2005, s. 13.

31 Ibidem, s. 24.

32 A. Cieślik, A. Zubik, M. Bańczarowska, „Starość” w narracjach kobiet w drugiej połowie życia, [w:] Starsze kobiety w kulturze i społeczeństwie, pod red. E. Zierkiewicz, A. Łysaka, Wyd. MarMar, Wrocław 2005 , s. 34.

33 Z. Szarota, op. cit., s. 44. 
sobie poradzić, są właśnie zmiany w aktywności seksualnej. Wśród osób starszych zdarzają się różne postawy z tym związane. K. Imieliński twierdzi, że można mówić o dwóch grupach osób:

- seniorach, dla których życie seksualne stanowiło zawsze istotną wartość - są to jednocześnie osoby obawiające się utraty tejże wartości w fazie starości,

- seniorach, którzy bardzo łatwo godzą się z etykietką osób aseksualnych - seks prawdopodobnie nigdy nie stanowił dla nich ważnej wartości, a czas starości mogą nawet postrzegać jako wybawienie od tej uciążliwej sfery ${ }^{34}$.

Należy pamiętać szczególnie o tej drugiej grupie, by przypadkiem nie popadać $\mathrm{z}$ jednej skrajności w inną i zmienić seniorom etykietkę z osób aseksualnych na takie, które za wszelką cenę powinny być seksualne, a zatem znów narzucić im presję, tym razem innego rodzaju. Seksualność ludzka jest bardzo intymnym i delikatnym zagadnieniem, a co za tym idzie, niezwykle ważne są tutaj różnice międzyosobowe.

Z kolei inny znany polski seksuolog, Z. Lew-Starowicz pisze o tym, że literatura przedmiotu wyróżnia 3 zasadnicze postawy:

- obronną: ambicjonalna reakcja na niepowodzenia seksualne, strategie ucieczkowe, nieprzyznawanie się do niepowodzeń seksualnych, jednostka nie szuka pomocy specjalistycznej ani wsparcia u partnera/partnerki,

- destrukcyjną: rezygnacja $\mathrm{z}$ aktywności seksualnej w sytuacji pojawienia się problemów seksualnych, izolowanie się, często zmiany depresyjne,

- optymistyczną: jednostka stara się eliminować pojawiające się trudności seksualne oraz dokłada starań, aby jej stały związek z partnerem/partnerką był satysfakcjonujący ${ }^{35}$.

Przyjęcie każdej z tych postaw niesie ze sobą pewne, łatwe do przewidzenia, konsekwencje dla danej osoby, ale i dla jej partnera/partnerki oraz ich związku. Strategie ucieczkowe, izolowanie się, całkowite zarzucenie aktywności seksualnej itp. - wszystko to, jeśli nie jest przedmiotem szczerej rozmowy między kochankami, może mieć bardzo negatywny wpływ na ich relację, ponieważ druga strona będzie postawiona w sytuacji, której nie rozumie i może ją sobie racjonalizować w błędny sposób, np. obwiniając siebie. Zmiany w seksualności i atrakcyjności fizycznej mogą zresztą być przez seniorów postrzegane jako zdarzenie kryzysowe, a w związku z tym pożądana może być pomoc specjalisty w tym zakresie, i to nie tylko medyczna, ale także, a może przede wszystkim psychologiczno-pedagogiczna, związana z informowaniem, doradzaniem, wspieraniem.

Warto przypominać zarówno samym seniorom, jak i reszcie społeczeństwa, że seksualność stanowi integralną część ludzkiego życia, bez względu na wiek. Trafnie ujął to prof. Z. Izdebski, mówiąc na Forum III Wieku w 2011 roku: „Kwestia wieku w miłości nie powinna mieć znaczenia - miłość to po prostu miłość i ko-

\footnotetext{
34 M. Grabowska, op. cit., s. 32.

35 Ibidem, s. 34.
} 
niec. Nie ma co patrzeć na wiek"36. Mimo że twierdzenie, iż człowiek jest istotą seksualną i bez względu na wiek ma prawo do przeżywania miłości i życia seksualnego, jest czymś oczywistym, nie każdy jest w stanie je zaakceptować37. Tym bardziej, że wątek seksualności starszych osób spowija swoiste tabu, czyli kulturowy zakaz dokonywania pewnych czynów lub poruszania pewnych tematów, wynikający z obyczajowości i moralności, posiadający sankcje związane z jego ewentualnym naruszeniem ${ }^{38}$. Według Wojciecha Burszty sfera seksualności objęta jest tabu w większości kultur ${ }^{39}$.

Przełamanie tabu aktywności seksualnej seniorów może przyczynić się w sposób znaczący do poprawy jakości ich życia ${ }^{40}$, którego ważnym elementem pozostaje także seksualność. Włączenie tej problematyki do zakresu zainteresowań współczesnej geragogiki powinno stać się dla niej wyzwaniem, szczególnie, gdy uświadomimy sobie, iż zagadnienie to do tej pory poruszane było głównie z punktu widzenia medycznego, psychologicznego, kulturowego, czy antropologicznego, natomiast niewiele jest prac pedagogicznych $w$ tym zakresie.

Najważniejsze jest, by „nie pozwolić się mentalnie wykastrować: dać sobie wmówić, że w seksie starych jest coś brzydkiego, niestosownego, niewłaściwego, że stary satyr i erotomanka w pęczkach zmarszczek, że wyuzdanie, ohyda, wstręt" ${ }^{\prime \prime 1}$. Seksuolodzy mówią już coraz więcej o tym, że seksualność człowieka podlega co prawda przemianom $\mathrm{w}$ trakcie życia, ale nie wygasa i pozostajemy istotami seksualnymi do jego końca ${ }^{42}$. Ponadto może ona być wyrazem głębokiego uczucia, a nie tylko przejawem czystej fizyczności, należałoby ją zatem analizować w kontekście osoby jako całości, holistycznie. „Zachwyca to, że zaczynamy o tym mówić i dostrzegać istotność tego aspektu życia seniorów. Holistyczna koncepcja człowieka postuluje współzależność umysłu, ciała i ducha, nie możemy więc odmówić osobom starszym prawa do realizacji ich potrzeb, zarówno duchowych, jak i tych związanych z seksualnością"43. Ponadto do starości w ogóle potrzeba podejścia interdyscyplinarnego ${ }^{44}$, dlatego też współczesna geragogika

${ }^{36}$ M. Wysocka, Nie patrzmy na wiek, http://www.noweperspektywy.org.pl/materialy/press/puls_ medycyny_2011_05_25_2.pdf, dostęp: 7.06.2012.

37 M. Beisert, $\bar{W}$ poszukiwaniu modelu seksualności człowieka, [w:] Seksualność w cyklu życia człowieka, pod red. M. Beisert, PWN, Warszawa 2006, s. 8.

38 Zob. W. Kopaliński, Stownik mitów i tradycji kultury, Kraków 1994, za: A. Tyrpa, Losy stowa tabu w Polsce (od encyklopedii Orgelbranda do prasy popularnej), [w:] Tabu w języku i kulturze, pod red. A. Dąbrowskiej, ,Język a Kultura", t. 21, Wrocław 2009, s. 16; A. Dąbrowska, Zmiany obszarów podlegających tabu we wspótczesnej kulturze, [w:] Tom jubileuszowy, pod red. A. Dąbrowskiej, "Język a Kultura", t. 20, Wrocław 2008, s. 75.

39 W. Burszta, Antropologia kultury, Wyd. Zysk i s-ka, Poznań 1998, s. 15.

40 O jakości życia osób starszych w sposób wyczerpujący pisała Agata Kowgier, która zwróciła uwagę na różne sposoby definiowania tego pojęcia w zależności od przyjęcia perspektywy obiektywnej czy subiektywnej, punktu widzenia gerontologii czy medycyny, zob. A. Kowgier, op. cit., s. 54-60.

${ }_{41}$ B. Pietkiewicz, Urok siwych gotabków, http://www.polityka.pl/psychologia/poradnikpsychologiczny/1503434,1,milosc-na-starosc.read\#ixzz1qvLuImUS, dostęp: 3.06.2012.

${ }^{42}$ Ibidem.

43 A. Kowgier, op. cit.

44 Starość w perspektywie studiów pedagogicznych, pod red. A. Tokaj, Studia i Monografie Wyższej Szkoły Humanistycznej im. Króla Stanisława Leszczyńskiego w Lesznie, Leszno 2008, s. 8. 
powinna czerpać $\mathrm{z}$ wielu dziedzin wiedzy (np. andragogiki, geriatrii, rehabilitacji geriatrycznej, psychologii, demografii i socjologii), by móc dostrzec problemy życia $w$ tym okresie $z$ wielu różnych perspektyw i jak najbardziej efektywnie wpływać na polepszenie jakości życia seniorów. Ważne jest także pamiętanie o tym, że aktywność seksualna osób starszych determinowana jest przede wszystkim przez „częstotliwość kontaktów płciowych we wcześniejszych fazach życia, zdrowie fizyczne i psychiczne, czynniki psychologiczne"45. Chciałabym jeszcze raz podkreślić znaczenie tych ostatnich, na które niebagatelny wpływ mają właśnie funkcjonujące $\mathrm{w}$ społeczeństwie stereotypy i uprzedzenia.

A przecież, według Powszechnej Deklaracji Praw Seksualnych: „seksualność jest integralną częścią osobowości każdej istoty ludzkiej. Jej pełny rozwój zależy od zaspokojenia podstawowych ludzkich potrzeb, takich jak pragnienie kontaktu, intymności, ekspresji uczuć, przyjemności, czułości i miłości". [Każdy człowiek ma między innymi - przyp. autorka] „prawo do seksualnej równości. Odwołuje się ono do wolności od wszelkich form dyskryminacji, niezależnie od płci, orientacji seksualnej, wieku, rasy, klasy społecznej, religii ani fizycznej albo emocjonalnej niepełnosprawności. [Powszechne powinno być także prawo przyp. autorka] do wyczerpującej edukacji seksualnej. Jest ona procesem trwającym przez całe życie i powinny być $\mathrm{w}$ nią włączone wszystkie instytucje społeczne" ${ }^{\prime \prime 6}$. Wynikają z tego zatem dwie bardzo ważne rzeczy dla geragogiki. Po pierwsze, że wiek nie powinien prowadzić do dyskryminacji w zakresie seksualności. Po drugie, edukacja seksualna nie jest czymś, co dotyczy tylko i wyłącznie osób wkraczających w dorosłość, celem przygotowania ich do aktywności w tej sferze, ale że zapotrzebowanie na nią istnieje na każdym etapie życia. Być może dobrym pomysłem byłoby włączenie jej w zakres programowy zajęć dla seniorów na Uniwersytetach Trzeciego Wieku, czy położenie większego nacisku na ten temat $w$ różnych instytucjach i organizacjach działających na rzecz osób starszych? Brakuje bowiem konkretnej oferty edukacyjnej czy poradniczej dla seniorów $\mathrm{w}$ tej kwestii. Zresztą tak samo potrzebne jest poruszanie tej problematyki z młodymi ludźmi, by uświadomić im, że jesień życia nie jest czasem aseksualnym. Rzetelna edukacja w tym kontekście mogłaby zwiększyć poziom akceptacji społecznej dla aktywności seksualnej seniorów. Tymczasem niewiele się w tym kierunku robi. Ukazują się publikacje dotyczące tego zagadnienia, przeznaczone dla starszego odbiorcy. Niestety, mimo dużego bogactwa tematycznego tych pozycji ich wadą często jest fakt, iż są one pisane zbyt medycznym językiem, a autorzy wikłają się w bardzo szczegółowe zagadnienia biologiczne, co może znacząco utrudniać zrozumienie przekazywanych treści przez adresatów takich lektur ${ }^{47}$. Zresztą z wywiadów przeprowadzonych przeze mnie z samymi seniorami wyni-

\footnotetext{
45 A. i A. Fabiś, op. cit., s. 162.

46 Powszechna Deklaracja Praw Seksualnych, http://www.funpzs.org.pl/deklaracja-praw-seksualnych.html, dostęp: 7.06.2012.

47 Przykładem może być publikacja Zygmunta Zdrojewicza, Seksualność człowieka w wieku późnej dorostości, która ukazała się w 2011 roku.
} 
ka, że ich zdaniem temat seksualności seniorów poruszany jest głównie w gabinetach lekarskich oraz $\mathrm{w}$ dostępnych tam ulotkach, jednakże niejednokrotnie właśnie ich zawiły język sprawia, że pozostają one całkiem niezrozumiałe, a więc i nieprzydatne dla przeciętnego starszego człowieka. Moim zdaniem, ignoruje się w przestrzeni publicznej temat seksu seniorów z perspektyw innych niż tylko i wyłącznie medyczna (a i to czyni się niezbyt często). Nie prowadzi się akcji społecznych na ten temat, debat medialnych czy innych tego typu przedsięwzięć, które mogłyby pozytywnie wpłynąć na postrzeganie tego zagadnienia zarówno przez samych seniorów, jak i młodsze pokolenia.

Aby sprawdzić, jak sami seniorzy postrzegają temat seksualności w jesieni życia i czy uważają, że jest ona objęta tabu, a jeśli tak, czy należy z tym walczyć, przeprowadziłam badania jakościowe, składające się z 20 wywiadów swobodnych (12 kobiet i 8 mężczyzn). Badani pochodzili z Wrocławia i Rawicza, czyli zarówno ze środowiska wielkomiejskiego, jak i małomiasteczkowego ${ }^{48}$. Przed przystąpieniem do badań musiałam zdefiniować, w którym momencie rozpoczyna się starość. "Jak twierdzi J. Piotrowski (1973), starość jest zjawiskiem kulturowym, wywołanym na podłożu biologicznym, związanym z osłabieniem sił (inwolucją). Nie ma żadnego obiektywnego czy przyrodniczego progu starości. Wiązanie początku starości z wiekiem chronologicznym 70, 65, 55 lat jest czysto umowne, konwencjonalne (...). [Również - przyp. autorka] wiele koncepcji medyczno-biologicznych głosi, że początek starzenia się jest nieuchwytny" 49 . Przyjęłam zatem, zupełnie umownie, że wywiady przeprowadzę z osobami powyżej 55. roku życia, a ostatecznie wśród badanych znalazło się 8 osób w wieku 55-65 lat, 7 osób w wieku 66-80 lat oraz 5 osób w wieku powyżej 80 lat.

Każdy ze swoich wywiadów zaczynałam od pytań „czym jest starość?" oraz "kiedy się ona zaczyna?". Wśród odpowiedzi dominowały wątki odnoszące się do zakończenia aktywności zawodowej, okresu odpoczynku i spokoju, co obrazują poniższe wypowiedzi badanych:

- Starość to wiek, kiedy nie trzeba pracować. Czas opieki nad wnukami (Barbara, 71 lat).

- Starość to wiek, kiedy człowiek potrzebuje spokoju, odpoczynku i jest mniej aktywny (Włodzimierz, 66 lat).

Pojawiały się także bardzo smutne odpowiedzi, ukazujące starość jako czas osamotnienia:

- To ciężka niedotężność, coś, co się Panu Bogu nie udało. Wtedy człowiek staje się niepotrzebny, jest ciężarem (Stefania, 87 lat).

Ponadto, zdaniem prawie wszystkich badanych, nie da się jednoznacznie określić początku starości. Zdecydowana większość osób wskazywała na rolę subiektywnych odczuć w jego definiowaniu. Często wspominano o problemach ze zdrowiem oraz o roli zaprzestania aktywności zawodowej jako o kryteriach defi-

48 Rawicz to małe miasteczko (około 25 tys. mieszkańców) w województwie wielkopolskim. http://powiatrawicki.pl/portal/index.php?option $=$ com_content\&task $=$ view\&id $=45 \& I t e m i d=46$, dostęp: 2.06.2012.

49 Z. Szarota, op. cit., s. 22- 23. 
nicyjnych początku starości. Warta odnotowania jest także wypowiedź, która kładzie nacisk na to, że utrata życiowego partnera/partnerki może skutkować przyspieszeniem procesów starzenia się: Osoby samotne szybciej się starzeja (Włodzimierz, 66 lat). To krótkie zdanie dobitnie pokazuje, jak ważna jest obecność i wsparcie bliskich osób dla zdrowia fizycznego i psychicznego seniorów.

Kolejną kwestią poruszaną $\mathrm{w}$ trakcie przeprowadzonych wywiadów było to, czy seks jest w ogóle ważny dla osób w jesieni życia. Tutaj badane osoby również wskazywały na znaczenie stanu zdrowia, temperamentu, ale też różnice między poszczególnymi jednostkami oraz na rolę, jaką odgrywają uczucia:

- Zależy od temperamentu i zdrowia (Wanda, 61 lat).

- Każdy ma inne potrzeby, ważne sa uczucia i zdrowie (Piotr, 66 lat).

Pojawiały się także wypowiedzi, w których stanowczo akcentowano to, iż ludzka seksualność nie zanika z wiekiem: Wiek nie ma tu nic do rzeczy. Każdy potrzebuje czułości! (Maria, 74 lata). Warta zacytowania jest odpowiedź pewnej pani: Oczywiście, że jest, tylko o tym się nie mówi (Krystyna, 68 lat). Pokazuje ona najlepiej, że sami seniorzy zauważają problem tabuizacji tego tematu.

W dalszej części prowadzonych wywiadów pytałam o to, czy badani rozmawiają na temat seksu, i ewentualnie z kim to robią. Większość badanych mówiła, że rozmawia o tym ze współmałżonkiem/partnerem; ewentualnie z lekarzem. Tylko 5 osób (wyłącznie kobiet) wskazało jeszcze na rozmowy ze znajomymi i przyjaciółkami. Natomiast kilka osób wyznało, że o seksie w ogóle rozmawiają bardzo rzadko, prawie wcale. Wyniki te wskazują na to, że temat seksualności nie jest przez badanych seniorów poruszany w sposób swobodny i stanowi obszar zarezerwowany jedynie dla najbliższych osób.

Zdaniem badanych, również media nie poruszają zbyt często tego tematu. Tylko 1 osoba wyraziła przekonanie, że nie unikają one tej problematyki. 4 osoby stwierdziły, że jest ona ukazywana w prasie, radiu, telewizji oraz w Internecie, ale traktuje się ją w sposób żartobliwy, nieraz nawet obraźliwy. Według większości, temat ten jest nieobecny w mediach. Podkreślano jego niemedialność oraz to, że seks pokazuje się tylko w kontekście młodości i piękna. Nie ma tego w mediach. Jeśli $j u \dot{z}$, to $w$ serialach, albo małe epizody w filmach, ale na pewno nie polskich (Jadwiga, 59 lat). Cytowana wypowiedź podkreśla także specyfikę polskiej kultury, która w porównaniu z Zachodem jest, według niektórych, bardziej zamknięta na pewne tematy i silniej tabuizuje niektóre sfery życia indywidualnego i zbiorowego.

Dwa poprzednie pytana stanowiły wstęp do najważniejszej kwestii, mianowicie, czy osoby starsze uważają, że ich seksualność stanowi temat tabu, i to zarówno $\mathrm{w}$ perspektywie ogólnospołecznej, jak i na gruncie jednostkowych biografii. Zdecydowana większość badanych twierdziła, że tak. Kilka osób nie potrafiło jednoznacznie stwierdzić. Wielokrotnie podkreślano różnice między młodszymi i starszymi seniorami:

- Dla młodszych seniorów może coraz mniej, ale dla osób urodzonych przed wojna na pewno. Oni byli inaczej wychowani. Poza tym, to zależy też od wyksztatcenia (Bogdan, 68 lat). 
- Na pewno tak, chociaż na szczéście ci młodsi [seniorzy - przyp. autorka] coraz częściej o tym rozmawiaja (Włodzimierz, 66 lat).

Poza tym badani dostrzegali również nieobecność tego tematu w przestrzeni publicznej, jego spychanie na margines dyskusji o seksualności w ogóle.

W rozwinięciu tego wątku chciałam się dowiedzieć, czy w takim razie fakt, iż seksualność seniorów przez większość badanych została uznana za objętą tabu, stanowi dla nich problem, czy chcieliby, aby taka sytuacja uległa zmianie. Wśród wszystkich wypowiedzi sedna zagadnienia dotykają przede wszystkim dwie:

- Problem... trudno stwierdzić. Trochę szkoda, że mało się o tym mówi, bo później jak człowiek czegoś nie wie, to nawet nie wiadomo kogo spytać, bo to wstyd przecież w tym wieku, a i lekarza nie wypada o wszystko pytać (Maria, 74 lata).

- Chyba tak, bo przecież dzisiaj to o wszystkim się mówi, to można by i o tym. Ale starość jest brzydka i niepotrzebna, więc się nie mówi. (...) Kiedyś chciałam porozmawiać o tym ze znajoma, to mi odpowiedziała, że w tym wieku to już lepiej myśleć o oszczędzaniu na pogrzeb, niż o takich rzeczach... (Jadwiga, 59 lat).

Poruszają one dwa ważne aspekty tego zagadnienia. Znajduje $\mathrm{w}$ nich potwierdzenie teza o tym, że istnieje zapotrzebowanie wśród seniorów na działania edukacyjne, poradnicze $\mathrm{w}$ kwestii seksualności. Poza tym ukazują one poczucie wstydu, zażenowania i rozżalenia, że starość powszechnie postrzega się jako aseksualną, a osobom starszym nie wypada już zajmować się tą sferą życia. Określenie starości przez jedną z badanych jako brzydkiej i niepotrzebnej uwidacznia jej przekonanie o niskim statusie społecznym tego etapu życia. Właśnie tutaj swoje zadanie ma do odegrania edukacja.

Poglądy podobne do powyższych dostarczają dowodów na to, jak ważny jest społeczny wizerunek starości dla samooceny i dobrostanu psychicznego osób starszych. Dlatego też w swoich badaniach poruszyłam również kwestię odbioru seksualności seniorów przez młode pokolenia. Odpowiedzi na to pytanie były najbardziej zróżnicowane. Badani często wskazywali na dystans międzypokoleniowy i różnice między generacjami jako czynniki, które sprawiają, że trudno ocenić, co na podany temat mogą myśleć młodzi ludzie: Nie wiem... Każdy w pewnym wieku ma inne potrzeby, czasem bardziej liczy się czułość... Trudno powiedzieć, bo młodzi generalnie mają inny pogląd na życie (Józef, 85 lat). Widoczne było również pewnego rodzaju zakłopotanie, spowodowane tym pytaniem, które być może wskazywało na to, że badani obawiają się tego, jak są odbierani przez młodzież, a jednocześnie jest to dla nich istotne. Często uciekali oni od bezpośredniego odpowiedzenia na pytanie i formułowali odpowiedzi w tonie życzeniowym: No ja mam nadzieje, $\dot{z} e$ młodzi patrza na to jakoś tak normalnie. Tak bym chciała, żeby było...(Barbara, 71 lat).

Zagadnieniem końcowym poruszanym $w$ przeprowadzonych rozmowach było to, czy w ogóle potrzebne jest częstsze podejmowanie tematu seksualności seniorów, np. w mediach, ośrodkach edukacyjnych, za pomocą kampanii społecznych, czy w jakikolwiek inny sposób. Najważniejszy wniosek z tej części badań był taki, że nie pojawił się ani jeden głos, który negowałby taką potrzebę 
i uznawał ją za pozbawioną sensu. Seniorzy wyrażali opinie podkreślające naturalność potrzeb seksualnych osób starszych, co już samo w sobie wskazuje na to, że należy o tym mówić: Seks w tym wieku nie jest już na pewno niczym ładnym, ale jest. Starsze osoby też mają swoje potrzeby (...). Dlatego trzeba więcej o tym mówić (Jadwiga, 59 lat). Zdarzały się też wypowiedzi sugerujące, jakie konkretnie tematy powinny być poruszane oraz w jakiej formie: Tak... głównie jeśli chodzi o kwestie zdrowia. Ale raczej przydatoby się coś na tamach prasy, bo osoby starsze częściej czytaja gazety, niż np. używaja Internetu (Barbara, 71 lat). Pozwoliłam sobie podsumować zebrane opinie jedną krótką wypowiedzią: No przecież mówić o tym nigdy nie zaszkodzi. Zawsze lepiej więcej wiedzieć, niż wiedzieć za mało (Irena, 60 lat). Zdanie to w sposób bardzo przystępny obrazuje przekonanie o roli edukacji i o jej potrzebie.

Podstawową konstatacją płynącą z przeprowadzonych dociekań jest potwierdzenie wniosków z badań wcześniejszych ${ }^{50}$, mianowicie, że starość zdecydowanie nie jest aseksualna. Jednak ważniejsze od tego niezaskakującego już stwierdzenia jest to, że w wielu wypowiedziach badanych osób przejawia się żal, czy poczucie presji społecznej, że osoby starsze nie powinny się już zajmować tematem seksu. Badani seniorzy dostrzegają brak tego zagadnienia $w$ medialnym dyskursie oraz w praktyce życia codziennego i jednocześnie uważają, że powinno się to zmienić i że warto o tym mówić.

Dlatego też chciałam wyrazić przekonanie, że tabu seksualności seniorów powinno stać się przedmiotem zainteresowania współczesnej geragogiki, której zadaniem jest między innymi obalanie stereotypów na temat starości i podnoszenie jakości życia ludzi w starszym wieku. Geragodzy, wychodząc z holistycznej wizji człowieka, nie powinni ignorować sfery seksualnej osób starszych, ale wspierać procesy adaptacyjne związane również ze zmianami w tym zakresie. Ponadto edukacja dotycząca seksualności w jesieni życia powinna obejmować zarówno osoby starsze, jak i młodsze pokolenia, celem obalania negatywnych stereotypów, tworzenia lepszego wizerunku starości i kształtowania bardziej pozytywnych postaw względem seniorów, co wpłynie także na ich samoocenę i sposób odczuwania własnej starości. Dowodem na to mogą być badania dotyczące wpływu czynników kulturowych i etnicznych na seksualność osób starszych, które zostały przeprowadzone przez Winna i Newtona w 1982 roku, poprzez porównanie tego zagadnienia w 106 różnych kulturach świata. Wśród wniosków z tego projektu badawczego na uwagę zasługuje na pewno to, iż oczekiwania kulturowe

50 Na przestrzeni lat przeprowadzonych zostało wiele badań dotyczących seksualności osób starszych. Warto tu przytoczyć chociażby te zrealizowane przez Pfeiffer i współpracowników (1969), Brecher (1984), Kivele (1986), Bretschneider, McCoy (1988), Marsiglio, Donnely (1991), Bergstrom-Walan, Nielsen (1990) czy Call, Sprecher i Shwartz (1995). Jednak wszystkie one miały charakter ilościowy i koncentrowały się głównie na zbadaniu aktywności seksualnej seniorów, pomiarów, jak często uprawiają oni seks. Poza tym, badacze ci poddawali analizie różne grupy wiekowe. Niektórzy za osoby w późnej dorosłości uznawali te, które przekroczyły 60. rok życia, inni 70., a jeszcze inni 80. Nastręcza to problemy w porównywaniu osiągniętych wyników. Jednak wniosek ze wszystkich tych badań jest jednoznaczny: seniorzy są aktywni seksualnie. Zob. M. Cichocka, op. cit., s. 219-225. 
i społeczne nastawienie względem seksualności seniorów, jeśli są pozytywne wspierają aktywność seksualną w jesieni życia; jeśli negatywne - osłabiają ją. Widać zatem, jak wielkie znaczenie mają postawy społeczne wobec tego tematu i w związku z tym, jak wielką rolę do odegrania ma edukacja ${ }^{51}$. Społeczeństwo powinno nauczyć się rozumienia specyfiki życia osób starszych, poszanowania ich potrzeb oraz problemów. Ignorowanie tego tematu lub postrzeganie seksu seniorów w kategoriach czegoś nieestetycznego i niemoralnego może być traktowane nawet jako przejaw ageizmu, a już na pewno jako element przemocy symbolicznej, która sprawia, że sami seniorzy zaczynają czuć, że nie mają prawa do szczęśliwego i pełnego przeżywania tej części swojej osobowości, jaką jest seksualność. Zadaniem współczesnej geragogiki powinno zatem być korzystanie także z założeń edukacji emancypacyjnej, która pobudza do krytycznej refleksji nad mechanizmami opresji i która zauważając obszary niesprawiedliwości społecznej i marginalizacji, prowadzi do ich zmniejszania za pomocą dystrybucji wiedzy52.

\section{Summary}

The taboo of senior's sexuality as a challenge for modern geragogics

The population is ageing and, according to demographers, this phenomenon will be subject to even greater intensification. Despite the fact that increasingly we recognizes the specific problems of people in the autumn of life, we still have to deal with ageism, and still topics such as senior's sexuality remains taboo. In addition, the prevailing consumerism and the cult of youth and body seems to detract any possible discussion on the margins of social life. Besides, existence of numerous myths and stereotypes preserve not always truthful picture of the sexual activity of older people. At the same time, social sciences more often covers necessity of learning both to old age, in old age, and that education's task should be breaking the taboos of various kinds, which relates to seniors. Moreover, the need for education that addresses both older people themselves and the rest of society, in shaping the attitude of understanding and acceptance, to combat stereotypes and ignorance of the problems affecting this age group, which in turn has the effect of improving the quality of their lives, becomes more apparent lately. The purpose of this paper is to demonstrate that the taboo of senior's sexuality should become the subject of interest, the challenge for contemporary geragogics. The inspiration for this writing were interviews with seniors, so that this issue is outlined, based on the perspective of those concerned.

51 M. Cichocka, op. cit., s. 225.

52 M. Czerepaniak-Walczak, Pedagogika emancypacyjna. Rozwój świadomości krytycznej człowieka, GWP, Gdańsk 2006. 